
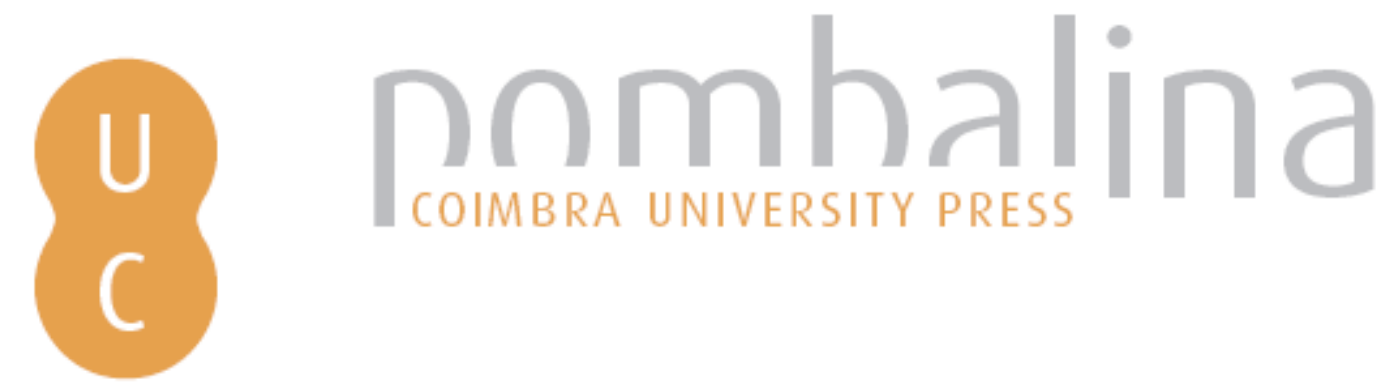

\title{
Experimental characterization and analysis on fire whirls using forest fuels
}

Autor(es): $\quad$ Pinto, Cláudia; Raposo, Jorge; Viegas, Domingos Xavier

Publicado por: Imprensa da Universidade de Coimbra

URL

persistente:

URI:http://hdl.handle.net/10316.2/44563

DOI:

DOI:https://doi.org/10.14195/978-989-26-16-506_46

Accessed : $\quad$ 26-Apr-2023 12:35:58

A navegação consulta e descarregamento dos títulos inseridos nas Bibliotecas Digitais UC Digitalis, UC Pombalina e UC Impactum, pressupõem a aceitação plena e sem reservas dos Termos e Condições de Uso destas Bibliotecas Digitais, disponíveis em https://digitalis.uc.pt/pt-pt/termos.

Conforme exposto nos referidos Termos e Condições de Uso, o descarregamento de títulos de acesso restrito requer uma licença válida de autorização devendo o utilizador aceder ao(s) documento(s) a partir de um endereço de IP da instituição detentora da supramencionada licença.

Ao utilizador é apenas permitido o descarregamento para uso pessoal, pelo que o emprego do(s) título(s) descarregado(s) para outro fim, designadamente comercial, carece de autorização do respetivo autor ou editor da obra.

Na medida em que todas as obras da UC Digitalis se encontram protegidas pelo Código do Direito de Autor e Direitos Conexos e demais legislação aplicável, toda a cópia, parcial ou total, deste documento, nos casos em que é legalmente admitida, deverá conter ou fazer-se acompanhar por este aviso.

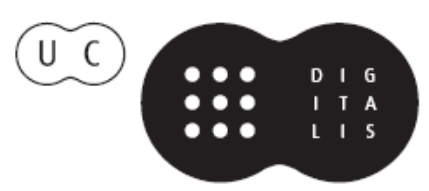




\section{ADVANCES IN}

\section{FOREST FIRE RESEARCH}

\section{8}

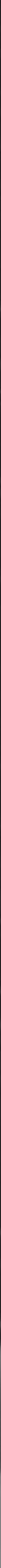




\title{
Experimental characterization and analysis on fire whirls using forest fuels
}

\author{
Cláudia Pinto*; Jorge Raposo; Domingos Xavier Viegas \\ Forest Fire Research Centre (CEIF), ADAI-LAETA, University of Coimbra. Coimbra 3030-289, \\ Portugal, \{claudia.pinto@adai.pt*\}
}

\begin{abstract}
During a forest fire the formation of fire whirls can be observed but their characteristics and evolution are still difficult to predict. Due to the high thermal energy released, fire whirls can become a danger to firefighters and are, by their complexity and dangerousness, a way of extreme fire behavior that is poorly understood.

This work presents a study on the formation of fire whirls with vertical axis on wildfires at laboratory scale that analyses the influence of the variation of the following parameters: fuel load, density, fuel configuration, imposition of forced flow with different velocities through the use of fans. Comprehensive measurements were performed in order to establish correlations of the burning rate, heat release rate, flame height, temperature and velocity of fire whirls, and to clarify the similarities and differences between a fire whirl and a 'normal' fire, i.e., one in which vortex formation is not observed. Fire whirl experiments were performed in a vertical channel with a quadrangular section of $1 \times 1 \mathrm{~m} 2$ with a height of $7.8 \mathrm{~m}$, the fire whirl generator, using dried shrubs, which is a fuel mainly composed by heather (Erica australis) and gorse (Pterospartum tridentatum) quite common in forested areas in Central Portugal and in several Mediterranean climate regions.

Given the transient nature of the experiments relationships between time correlated parameters or with average or extreme values were established. Comparison with similar experiments showed that the properties of the flames generated with the present configuration of the fire whirl generator are similar to fire whirls produced in other laboratory studies and with full scale fire whirls. The maximum heat release power was of the order of $1 \mathrm{MW}$ which is higher than the reported values for similar laboratory tests. The results show that forced flow increases dramatically the burning rate and reduces the time needed to achieve a high rate of energy release. On the other hand, from a certain value of forced flow it is observed that the values of the burning rate and flame height decrease, thus existing a critical wind velocity for optimal fire whirl development. Comparison with results of other sources show that the flames that are generated in the present fire whirl generator are in a transition from fire whirl to pool fire regime and that it is possible to scale up some flow and thermal properties of field scale fire whirls and to derive predictive models on the basis of laboratory scale experiments.
\end{abstract}

Keywords: Fire whirl, Extreme fire behavior, Forest fires, Forest fuels, Burning rates, Fire safety

\section{Introduction}

In certain circumstances, fires can cause great destruction and endanger the population and those who fight them, particularly in situations where the fire spreads under extreme conditions due to weather, fuel or topographical factors, which are likely to potentiate accidents (Viegas et al., 2017). Under these conditions fires with strong vorticity phenomena, associated to rapidly changing fire spread properties, as in the case of fire whirls, are among the most dangerous and difficult to control. We consider a fire whirl a vertical axis flow structure having a rotating flame in its core that can release very high amounts of energy and produce intense spotting.

As the amount of energy produced at laboratory scale vortices is small compared to those in wildland fires the scale up of results is of great importance when attempting to apply information from small-scale experiments to full-scale fire whirls. Several authors have examined this problem (see e.g 
Kwuana et al., 2011 and Kwuana et al., 2013), but no universal scaling parameters exist for air intake velocity, burning rate, flame base size, etc

The types of fuels used to conduct experimental studies are mostly liquid and gaseous, and it is therefore important to approach the study of fire whirls behavior through the use of forest fuels (Pinto et al., 2017).

The influence of the lateral wind velocity was studied by Kuwana et al. (2008) and a scaling law that predicts the critical wind velocity at which the most intense fire whirl was generated was developed and validated. It was observed too that in actual mass fires the occurrence of fire whirls is time-dependent, in contrast to well controlled small-scale laboratory experiments, but this finding was not explored.

The present work aims contributing to a better understanding on the formation of fire whirls and characterization of this phenomenon through the continuation of the previous work (Pinto et al., 2017). Comparison with results from other laboratory scale experiments and full size fire whirls and pool fires showed that it is possible to derive predictive models for this type of fire whirls in a wide range of scales.

\section{Experimental Methodology}

The tests were performed at Laboratory for Forest Fire Studies (LEIF) in the Fire Whirl Generator (FWG) apparatus (Pinto et al., 2017) consisting of a vertical channel with a quadrangular section of $1 \times 1 \mathrm{~m}^{2}$ with a height of $6 \mathrm{~m}$ with two sides made of tempered glass and the other two made of steel sheet. The base of the FWG has a section of $2 \times 2 \mathrm{~m}^{2}$ and $1.8 \mathrm{~m}$ height tapering to the $1 \times 1 \mathrm{~m}^{2}$ section of the main channel section that is open at the top (see Figure 1). Each corner of the channel has a vertical opening $10 \mathrm{~cm}$ wide to induce tangential air entrainment. Inside the base of FWG there is a platform of $1 \times 1 \mathrm{~m}^{2}$ covered by ceramic tiles to support the fuel container. A set of four axial fans Rosenberg DR 630-4.6LA was attached to the base of the FWG to induce a tangential flow to create a forced vortex inside the combustion chamber. In the present experiments the inlet velocities, $v_{i}$, value in the range from $0 \mathrm{~m} / \mathrm{s}$ until $5 \mathrm{~m} / \mathrm{s}$ were used. The fuel containers were made of a metallic grid welded to form a cylinder open on the top and five different containers with $0.350 \mathrm{~m}, 0.500 \mathrm{~m}, 0.800 \mathrm{~m}$ and $1.120 \mathrm{~m}$ diameter were used. The solid porous fuel used consisted of dried shrubs, mainly composed by heather (Erica australis) and gorse (Pterospartum tridentatum) quite common in forested areas in Central Portugal and in several Mediterranean climate regions. The fuel in the container was placed on the plate inside the FWG, the ignition was initiated along the perimeter basis of the container using a gas burner and the fan frequency was tuned in order to achieve the desired flow velocity. The tests were made assuring the same conditions of ambient temperature and preparation methodology. In these tests the fuel load was $4 \mathrm{~kg}$ (dry mass) for all fuels.

The mass loss values were recorded directly to an Excel sheet with a time interval of one second, by RSKey v.1.40 software, using a laptop connected to the electronic scale. The velocities were measured using four Pitot tubes type $\mathrm{S}$, two of them measuring the radial direction flow velocity (one at $2.70 \mathrm{~m}$ height and the other at $4.20 \mathrm{~m}$ height) and the other two measuring the tangential direction flow velocity, at the same heights. All measuring points were located $10 \mathrm{~cm}$ from the axis of the vertical channel. Temperatures were measured using four thermocouples type $\mathrm{K}$ placed in the same locations of the Pitot tubes. A data acquisition system (LabVIEW software and National Instruments hardware) was used to register the values of temperature and airflow velocity during the experiments.

Two cameras were used for recording images: a Sony high definition video camera and a Cannon photographic high performance digital camera. The video camera was always in the same place and the recorded images were used to measure flame diameter and flame height. 

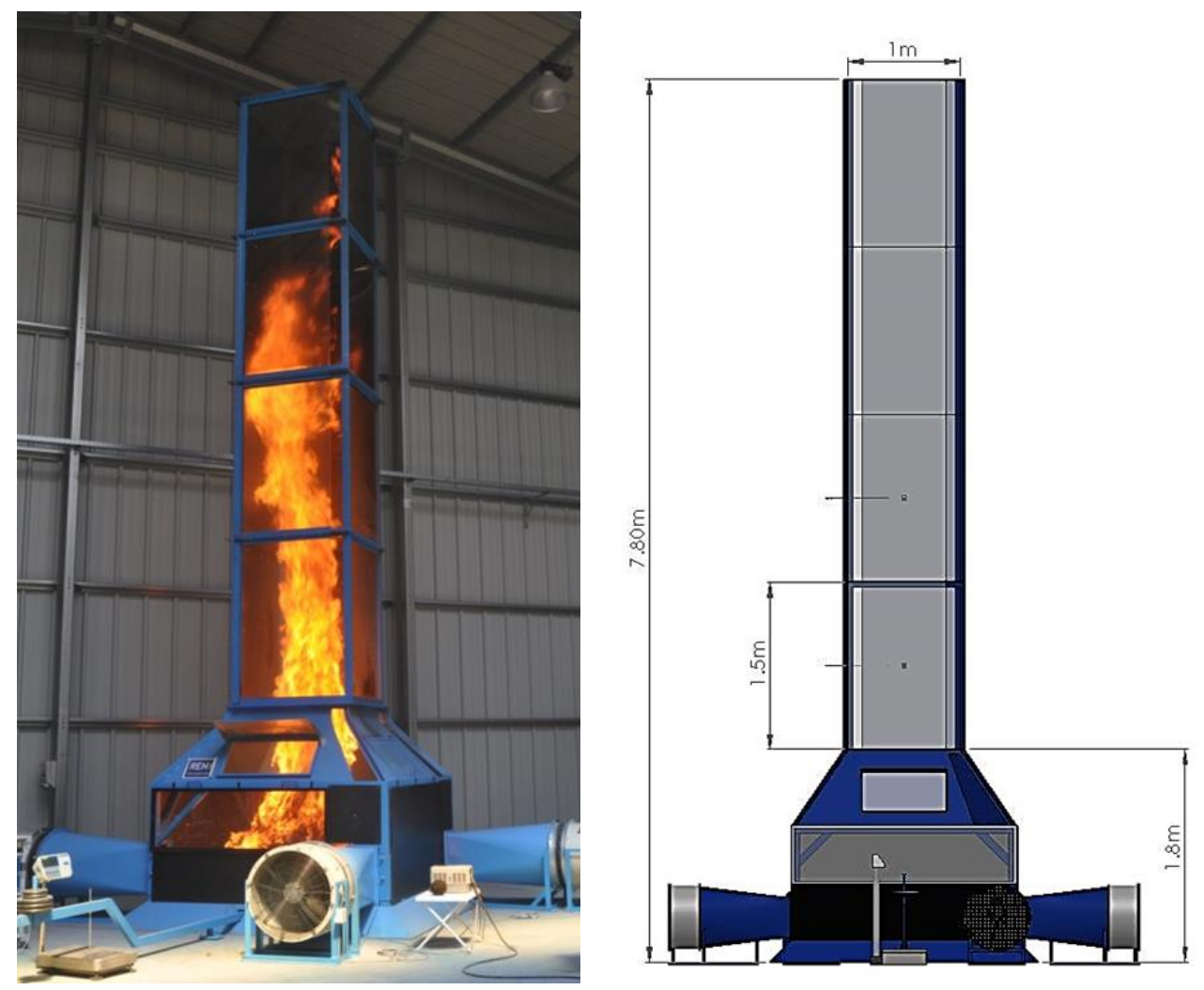

Figure 1 - Fire Whirl Generator (FWG) apparatus

\section{Results}

\subsection{Use of Forest fuels}

The use of natural forest fuels, namely shrubs, makes the study and visualization of the fire whirls more realistic and similar to fire whirls produced in forest fires. The amount of heat released, the mass loss rate, the flame height and diameter, the velocities and temperature change in the course of time as the mass loss rate is not constant during each test as can be observed in Figure 2a. Therefore, time dependent phenomena can be studied in these experiments and the variation of one parameter with another one can be checked using either instantaneous, average or the maximum values of the relevant parameters. Assuming that the behavior is quasi static correlations between time dependent variables can be made in a single test for a range of values of the relevant parameters (e.g., see Figure 2b).

For some parameters the maximum value was not well defined; in these cases, the average of five higher values in the test was considered as the maximum value. The maximum values of the parameters analysed here are higher than those obtained in similar size tests performed with liquid fuels, as for example, in our study heat power released by these fire whirls is higher than $1 \mathrm{MW}$ (see Table 2 of (Pinto et al., 2017)) in comparison with $600 \mathrm{~kW}$ from fire whirls produced with liquid fuels by Lei et al. (2011) for containers with $500 \mathrm{~mm}$ diameter in both studies.

\subsection{Burning rate and Forced flow}

The burning rates of fire whirls depend on diameter of the container, $d_{c}$, similarly to those of general pool fires, but with a much higher increasing rate versus the diameter of the container. As can be seen in Figures. $2 \mathrm{a}$ and $2 \mathrm{~b}$, larger diameter containers, $\mathrm{d}_{\mathrm{c}}$, correspond to higher values of mass loss rate, $\dot{m}$, and lower values of burning duration. These results are in agreement with other author's studies (Lei et al., 2011 and Martin et al., 1976). 
a)

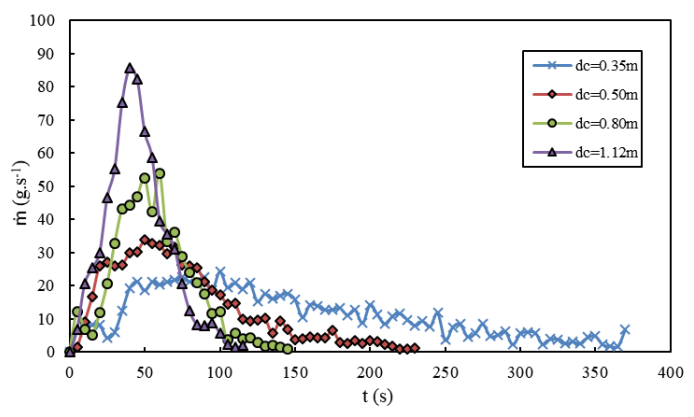

b)

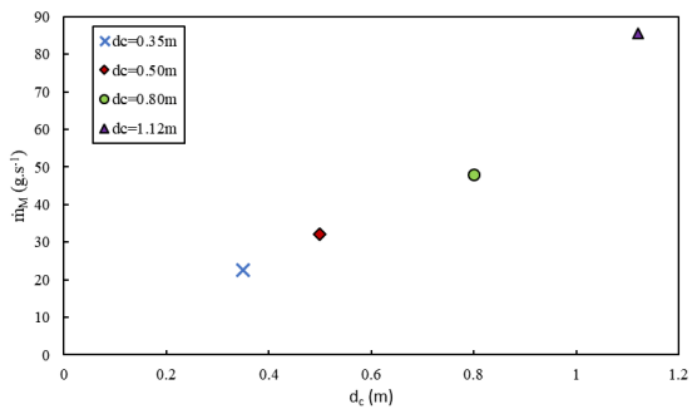

Figure 2 - (a) burning rate variation for different diameter containers $\left(d_{c}\right)$ as a function of time; b) maximum mass loss rate $\left(\dot{m}_{M}\right)$ as a function of diameter containers

Following the previous work (Pinto et al., 2017), in the present study the potential of the FWG was explored to extend the range of parameters (burning rate, heat release rate and flame height) tested through the use of other sensors, Pitot tubes and thermocouples, to analyse the flow and temperature, respectively. As the repetition of tests in other conditions yielded similar results we will present the results of only one test. The test was performed with no forced flow and using the container with 500 $\mathrm{mm}$ diameter. Figures $3 \mathrm{a}$ and $3 \mathrm{~b}$ show the temperatures, $T$, the velocities, $U$, and the mass loss rate, $\dot{m}$, as a function of time. It can be observed that like in Figure $2 \mathrm{a}$ the behavior of these parameters are time dependent in which temperatures, velocities and fuel mass loss rates are initially low and constant, since they coincide with the initial combustion of the shrubs, when the formation of the fire whirl has not yet occurred; the formation and development of the fire whirl starts from approximately 50 seconds after ignition, causing the increase of temperatures, velocity values and mass loss rate up to the peak; finally the values decrease until the fire whirl extinguishes. The values of the velocity remain non-null and constant after 300 seconds, at values of approximately $1.5 \mathrm{~m} / \mathrm{s}$, due to the heat released by the nonflaming residual combustion of shrubs.

The values of fuel mass loss rate and velocity were acquired at the same time instants and so can be related to each other, as shown in Figure 3c. It is interesting to notice the story of the fire whirl which can be divided in three phases: 1) formation and development for $\dot{m}$ between 0 and $40 \mathrm{~g} . \mathrm{s}^{-1}$ and rising $\mathrm{U}$ from the still condition (lower branch of the curve), 2) maximum development for $\dot{m} \approx 40 \mathrm{~g} / \mathrm{s}$ and $U \approx 7-8 \mathrm{~m} / \mathrm{s}$ (right upper corner of the curve), and 3 ) for decreasing $\dot{m}$ and $U$ (upper branch of the curve).

a)

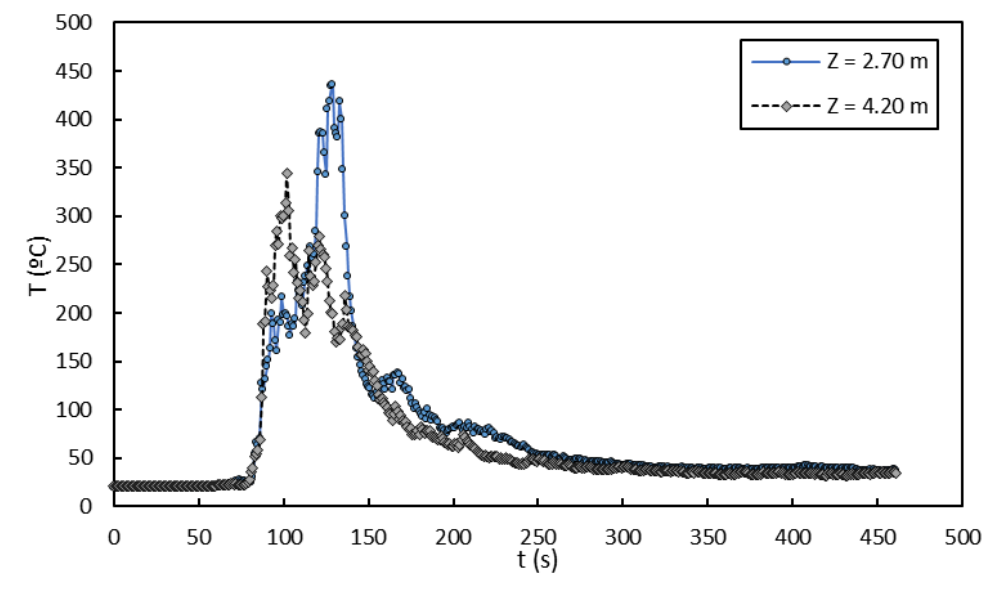

b) 

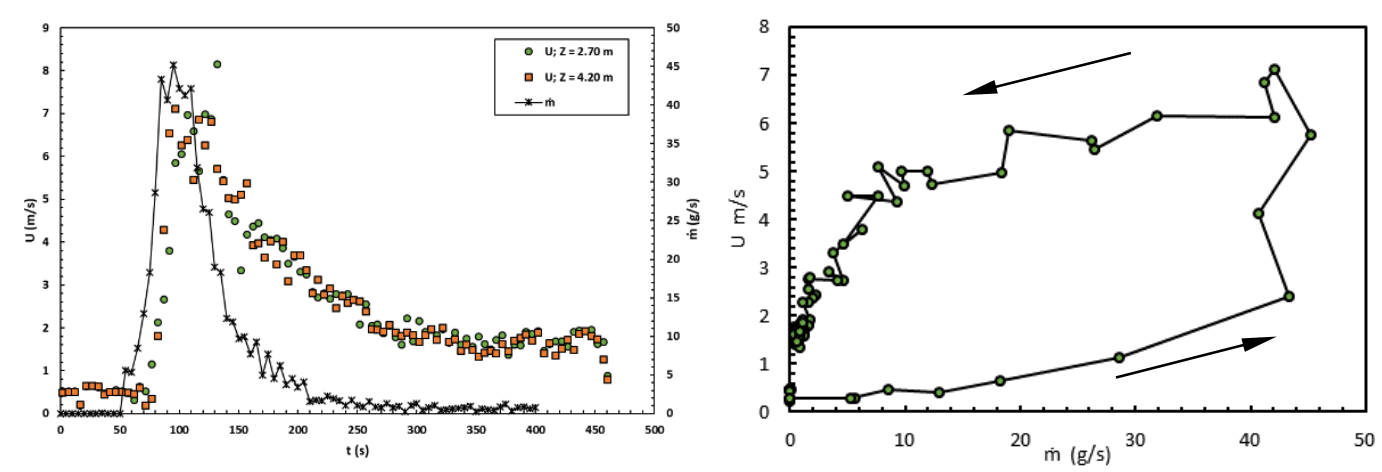

Figure 3 - Temperature, flow velocities and fuel mass loss rate measurements for different heights $(Z=2.70 \mathrm{~m}$ and $\mathrm{Z}$ $=4.20 \mathrm{~m}$ ): (a) temperature in function of time; $b$ ) velocity and mass loss rate in function of time; $c$ ) velocity as a function of mass loss rate for the 4.20 m height Pitot tube

The experimental results of the tests with forced flow, $v_{i}$, were compared with other tests in similar conditions in terms of fuel load with no forced flow $\left(\mathrm{v}_{\mathrm{i}}=0 \mathrm{~m} \cdot \mathrm{s}^{-1}\right)$. It was possible to evaluate the positive effect of vorticity on several parameters like flame height, $L_{M}$, mass burning rate and fire intensity. The results show that forced flow increases dramatically the burning rate and reduces the time needed to achieve high values of energy release. In Figures $4 \mathrm{a}$ and $4 \mathrm{~b}$ the maximum value of mass loss rate increases generally with the forced flow velocity, at the same time the average flame height increases a little $(+11 \%)$ and the average flame diameter, $d_{m}$, decreases significantly $(-33 \%)$. On the other hand, it is observed that there is a value of forced flow for which the flame height reaches its maximum (for $v_{i}=2.74 \mathrm{~m} . \mathrm{s}^{-1}$ ), decreasing for higher values of forced flow, meaning that fire whirls formation and development can be dependent of the amount of air entrainment or the ambient vorticity. This effect must be studied more carefully as it may be an indication of the existence of either a change of regime in the fire whirls development.

a)

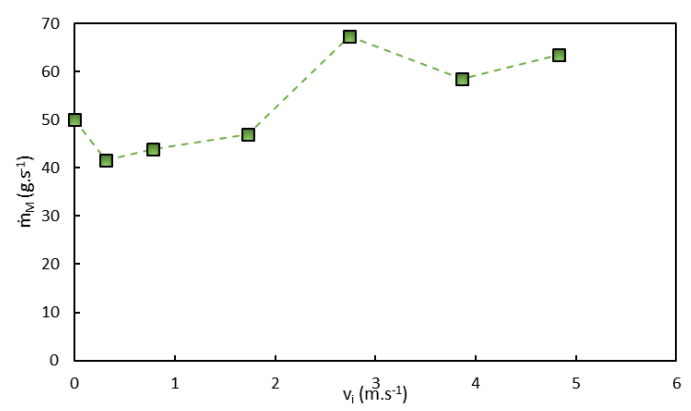

b)

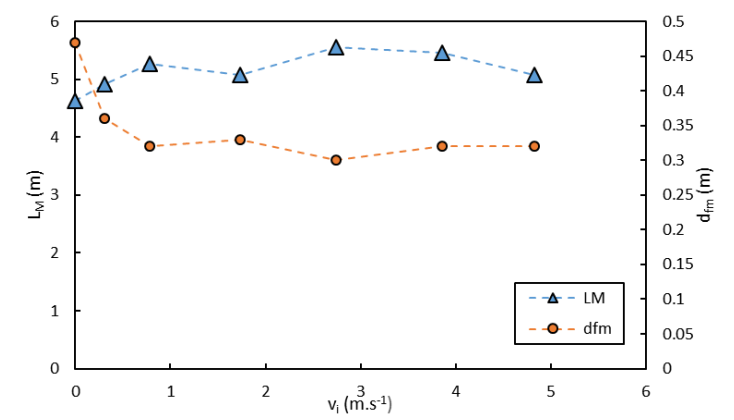

Figure 4 - Results for several air forced flow: (a) maximum values of mass loss rate; b) maximum values of height flame and diameter flame of fire whirl

\subsection{From laboratory scale to full scale fire whirls}

Using the present research, a relationship between the maximum flame height, $L_{M}$, and the size of the fuel bed, $d_{c}$, is proposed given by:

$$
L_{M}=a_{5} d_{c}^{b_{5}}
$$

Photos or video images of fire whirls can be used to obtain data on the two parameters that are used in Equation 1. Provided that there is some scale factor to assess vertical and horizontal dimensions and assuming that the flaming area at the base of the fire whirl - that is usually a circle - can be assimilated to the fuel bed or fuel container of the laboratory experiments we can use Equation 1 to estimate the properties of real scale fire whirls based on laboratory scale experiments. 
Our results together with those found in the literature are shown in Figure 5. The numbering used in Figure 5 is described in Table 1. Comparison with similar experiments showed that the properties of the flames generated with the FWG are similar to fire whirls produced in other laboratory studies. Our tests show that there is a transition from fire whirl to pool fire regime. Results from our tests with no forced flow and with forced flow (fire whirls) are presented with numbers 1 and 3, respectively. Results from fire whirls with liquid fuel (heptane) obtained by other authors are shown in this figure and fitted by curves 4 and 5; results from pool fires also with heptane are fitted by curves 6 and 7, and results from real fire whirls are shown by curve 9. Our results are in the middle of this range and seem to be in a transition between small laboratory scale tests and large scale field tests.

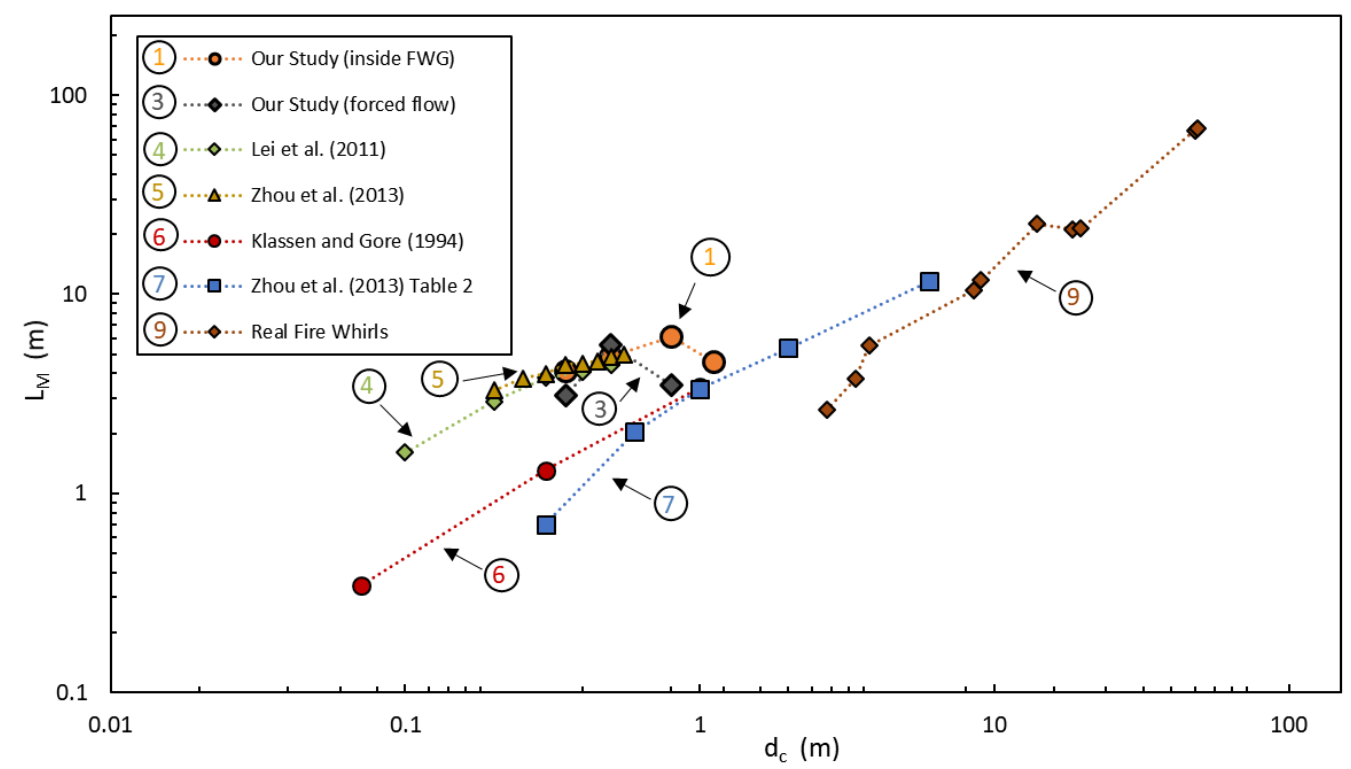

Figure 5 - Results of different studies of maximum flame height $\left(L_{M}\right)$ versus diameter of containers or the diameter of the base of the fire whirls. The sources of data that are indicated by a number are given in Table 1.

Table 1 - The coefficients that characterize the flame height vs the diameter of containers.

\begin{tabular}{lllll}
\hline Ref. & Description & $\mathrm{a}_{5}$ & $\mathrm{~b}_{5}$ & $\mathrm{R}_{5}{ }^{2}$ \\
& & & & \\
\hline (1) & Our Study (inside FWG) & 5.11 & 0.10 & 0.20 \\
(3) Our Study (forced flow) & 4.86 & 0.33 & 0.02 \\
(1) Lei et al. (2011) & 7.48 & 0.64 & 0.96 \\
(5) Zhou et al. (2013) & 7.48 & 0.44 & 0.97 \\
(6) Klassen and Gore (1994) & ${ }^{\mathrm{a}}$ & 3.48 & 0.86 & 0.99 \\
(7) Zhou et al. (2013) [Table 2] & 2.72 & 0.90 & 0.96 \\
(9) Real Fire Whirls & 1.09 & 1.06 & 0.98 \\
\hline${ }^{\mathrm{a}}$ Values from Table 2 of Lei et al. & & & \\
bValues from Table 2 of Zhou et al. & & &
\end{tabular}

\section{Conclusions}

In the present laboratory study medium-scale fire whirls were investigated. The major results are summarized as follows: 
- The parameters analysed change in the course of time as the mass loss is not constant during each test due to the use of natural fuels.

- The maximum values of the parameters analysed here are higher than those obtained in similar size tests performed with liquid fuels, as for example, heat power released by these fire whirls is higher than $1 \mathrm{MW}$ in comparison with $600 \mathrm{~kW}$ from fire whirls produced with liquid fuels.

- The burning rates of fire whirls depend on diameter of the container similarly to those of general pool fires, but with a much higher increasing rate versus the diameter of the container.

- The instantaneous values of fuel mass loss rate and flow velocity can be related to each other and it is possible to identify the process of formation and development of the fire whirl.

- The maximum value of mass loss rate and the average flame height increase generally with the forced flow velocity $(+11 \%)$. On the other hand, the average flame diameter decreases significantly $(-33 \%)$ with flow velocity.

- Our tests show that there is a transition from fire whirl to pool fire regime.

- Comparison with similar experiments showed that the properties of the flames generated with the FWG are similar to fire whirls produced in other laboratory studies and with full scale fire whirls. Relationship between the flame height and the size of the fuelbed is proposed.

\section{Acknowledgements}

This work was sponsored by the FCT under Projects FIREWHIRL "Vorticity Effects in Forest Fires" (PTDC/EMS - ENE/2530/2014) and Project FIREXTR "Prevent and prepare society for extreme fire events: the challenge of seeing the "forest" and not just the "trees" (PTDC/ATPGEO/0462/2014). The collaboration given to the experimental program that supports this paper by several collaborators is gratefully acknowledged.

\section{References}

Kuwana K, Sekimoto K, Saito K, Williams FA (2008) Scaling Fire Whirls, Fire Safety J., 43, 252 257.

Kuwana K, Morishita S, Dobashi R, Chuah KH, Saito K (2011) The burning rate's effect on the flame length of weak fire whirls. Proc. Combust. Inst. 33, 2425-2432.

Kuwana K, Sekimoto K, Minami T, Tashiro T, Saito K (2013) Scale-model experiments of moving fire whirl over a line fire, Proc. Combust. Inst. 34 (2), 2625- 2631.

Lei J, Liu N, Zhang L, Chen H, Shu L, Chen P, Deng Z, Zhu J, Satoh K, De Ris JL (2011) Experimental research on combustion dynamics of medium-scale fire whirl. Proc. Combust. Inst. 33, 2407-2415.

Martin R, Pendleton D, Burgess W (1976) Effect of fire whirlwind formation on solid fuel burning rates. Fire Technol. 12, 33-40.

Pinto C, Viegas DX, Almeida M, Raposo J (2017) Fire whirls in forest fires: An experimental analysis, Fire Safety Journal, Vol. 87, 37-48. (Doi:10.1016/j.firesaf.2016.11.004).

Viegas DX, Almeida M, Ribeiro LM, Raposo J, Viegas MT, Oliveira R, Alves D, Pinto C, Jorge H, Rodrigues A, Lucas D, Lopes S, Silva LF (2017) O complexo de incêndios de Pedrógão Grande e concelhos limítrofes, iniciado a 17 de junho de 2017. Centro de Estudos sobre Incêndios Florestais (CEIF/ADAI/LAETA), Universidade de Coimbra, Coimbra.

Zhou K, Liu N, Lozano JS, Shan Y, Yao B, Satoh K (2013) Effect of flow circulation on combustion dynamics of fire whirls. Proc. Combust. Inst. 34, 2617-2624. 